\title{
MULTIPLE INTELLIGENCES IN BASIC SCHOOL LEARNING
}

\author{
${ }^{1}$ Like Raskova Octaberlina \& ${ }^{2}$ Andi Asrifan (2021). \\ ${ }^{1}$ Universitas Islam Negeri Maulana Malik Ibrahim, Malang, Indonesia \\ ${ }^{2}$ Universitas Muhammadiyah Sidenreng Rappang
}

\section{ARTICLE INFO}

Keywords:

Multiple intelligences,

Learning in SD

\begin{abstract}
Intelligence is an individual's ability to solve problems, with knowledge, skills and experience. Basically, every person has several intelligences including linguistic, logical, math, visually, kinesthetic, interpersonal, intrapersonal, musical, and naturalistic intelligence. Yet each individual's combination and portion of intelligence is not the same depending on how the current intelligences are produced. By recognizing that every person has different types of intelligence, educators hope that they not only assume that students who are intelligent or successful are only intelligent students. University. University. Because besides students' skill in the academic field alone there are various other great potentials. The eight intelligences will act independently of each other in accompaniment. Based on various theories of intelligence, an instructor is able to indirectly master different methods of learning. To allow students to achieve optimum performance, the role of the teacher as an instructor, guide, trainer, consultant, reformer, creativity enhancer, generator and assessor.
\end{abstract}

\section{Introduction}

Learning is a shared relationship between learners and instructors. Learning can work together with enjoyable activities at primary school level, for example by playing. The child learns in this situation, but also plays. Learning done in this way is of consistency and effectiveness, whenever possible. Learning can be said to be successful if all the learning aspects are mutually beneficial in order to help children understand what they learn.

The communication mechanism that is happening in students of relatively mature ages is different between teachers and students in elementary schools. If pupils are taught to use all the sensory organs, this learning process will function well. Therefore, a learning model is needed, which can help to stimulate everyone's senses in a specific learning process. Multiple intelligence students should research the value of learning models while maximizing the full potential of intelligence, as the greatest possible production of intelligence can be enhanced, enriched, encouraged and trained. Educators are more wise, respectful and willing to encourage the growth of children. Multiple intelligences learning is more powerful by optimizing or improving them. In this paper we will speak about many intelligences in elementary schools in theory, comprehension, forms, characteristics and implications.

\section{Multiple Intelligences Theory}

Howard Gardner's theory of multiple intelligences uses psychological, anthropological and sociological cognitive and developmental dimensions to clarify the perception of the human being. Although this idea was researched several years ago, it was only presented in the book Frames of Mind by Gardner in 1983.

Howard Gardner's anxiety began what underlying his thought. According to him, until now, educators have misled themselves because they conclude that intelligence tests or IQ tests are the only way to assess a person's intelligence that is best utilized. Gadner also notes that the ability of human intelligence to solve problems existing in life, to find new problems to solve or find solutions, and the ability to construct and appreciate things in our society must also be measured.

In addition to measuring the ability of a person to understand and solve logic-math problems, Gardner and his colleagues who conducted research to develop this idea of multiple intelligences (as is done in an IQ test). Towards a solution of problems and outcomes, Gardner has provided ways to measure the potential of a person. 
Gardner conducted human brain studies and interviewed victims of stroke, prodigies and autism. On the basis of this study, Gardner's eight requirements for intelligence defined. This means that all eight kinds of intelligence are not only innate, but completely created. Gardner uses the following criteria:

\section{Location in the brain}

Gadner noted that persons with certain injuries or disorders often affect certain parts of the brain. This injury affects certain intelligences, but it does not affect other intelligences in any way. For example, in Broca (left front lobe), people who have sustained an injury will have difficulties in speaking but can still perform mathematics, dance, communicate feelings and communication with others. The main area of any form of intelligence in the brain lies in the neurological system of Table 1 below:

Table 1. The Neurological System In The Brain Which Is The Primary Area Of Each Kind Of Intelligence

\begin{tabular}{|c|c|c|c|}
\hline Kinds of Intelligence & Primary Region in the Brain & Kinds of Intelligence & Primary Region in the Brain \\
\hline Linguistics & $\begin{array}{l}\text { Left temporal lobe and lobe fronts } \\
\text { (including Broca \& Wernicke) }\end{array}$ & Spatial & $\begin{array}{l}\text { The back of the right } \\
\text { hemisphere }\end{array}$ \\
\hline Musical & Right temporal lobe & Intra personal & $\begin{array}{l}\text { Front lobe, lobe parietal, } \\
\text { limbic system }\end{array}$ \\
\hline Mathematical Logical & Left anterior and right parietal lobes & Mouse kines & $\begin{array}{l}\text { Cerebellum, basal ganglia, } \\
\text { motor cortex }\end{array}$ \\
\hline Interpersonal & $\begin{array}{l}\text { Front lobe, lobe temporal (especially the } \\
\text { hemispheres right), the limbic system }\end{array}$ & Natural is & $\begin{array}{l}\text { Lobe regions parietal left } \\
\text { which is important for } \\
\text { distinguishing "being alive } \\
\text { "with" inanimate objects " }\end{array}$ \\
\hline
\end{tabular}

\section{There is Evidence of Personality}

Gardner provides an example of some people who are very prominent in a specific type of intelligence but low in other intelligences or scientists (as Raymond in Rain Man's film) Each intelligence having a period of appearance and creation intelligence is shaped by the participation of cultural values. Music grows early and goes on until the age of one; visual awareness can be established in adulthood in the form of painting (as in the case of moses grandmother).

Table 2. Emerging Developments in Each Type of Intelligence.

\begin{tabular}{|c|c|c|c|}
\hline Intelligence & Emerging Development & Intelligence & Emerging Development \\
\hline Linguistics & $\begin{array}{l}\text { Exploding in childhood continues into old } \\
\text { age }\end{array}$ & Inter personal & The critical period of the first three years \\
\hline Musical & $\begin{array}{l}\text { Developing early, the genius sometimes } \\
\text { experiences a developmental crisis }\end{array}$ & Intra personal & $\begin{array}{c}\text { Establishment of boundaries for yourself and } \\
\text { others during the first } 3 \text { years }\end{array}$ \\
\hline Spatial & $\begin{array}{l}\text { 9-10 years old and sensitive artistically until } \\
\text { old age }\end{array}$ & Naturalist & $\begin{array}{l}\text { Appears dramatically in some children } \\
\text { developable through school / experience }\end{array}$ \\
\hline Mathematical - Logical & $\begin{array}{l}\text { Peaks in adolescence and early adulthood, } \\
\text { decreases after } 40 \text { years }\end{array}$ & Kinesthetic & $\begin{array}{l}\text { Varies, depending on the components of } \\
\text { strength, flexibility, gymnastic domain }\end{array}$ \\
\hline
\end{tabular}


Every type of intelligence has historic evidence, such as the rhythm of insects in search of flowers, musicals by antique musical musical instruments, etc. Each type of intelligence has historical evidence.

\section{Psychometric Finding Support}

The findings of a variety of regular psychological assessments verified the intellect of Gardner. Standardized intelligence assessment test in a contextual way (making use of the Wechsler intelligence scale for linguistic, logical mathematical, spatial, kinetic; etc.)

\section{Experimental Psychological Research Support}

The intellect tends to operate in isolation from the psychological activities. For example, readers are not inherently strong in mathematics.

\section{Each Intelligence has a Basic Set of Methods}

Any intelligence needs to have a certain working method which should work to drive each intelligence's particular activities. For example, Kinesthetic has a main working method: to mimic physical gestures, to master fine motor routines in buildings.

Ease Encode into the symbol system

Every intelligence has its own symbol.

Table 3. Symbol System in Each Kind of Intelligence.

\begin{tabular}{|c|c|c|c|}
\hline Intelligence & Symbol System & Intelligence & Symbol System \\
\hline Linguistics & Phonetic Symbols / eg & Spatial & Ideographic Symbols (Chinese writing) \\
\hline Musical & Musical notation, Morse code & Intrapersonal & Self symbol (in dreams \& artwork) \\
\hline Mathematical-Logical & Mathematical symbols & Kinesthetic & Sign Language, Braille \\
\hline Interpersonal & $\begin{array}{c}\text { Social symbols, expressions, } \\
\text { movementscue }\end{array}$ & Naturalist & Classification, habitat map \\
\hline
\end{tabular}

They are the parameters used for the separate identification of the seven intelligences. In 1999, Reframed, added naturalist intelligence, Gardner's Intelligence was subsequently released.

While this principle was initially not intended for use in classroom applications, a substantial number of educators adopt and adapt to learning. This theory allows teachers to assess the strengths and weaknesses of classroom students. Gardner's research will express this and guide students in any given subject to develop their ability. Lectures to address the needs of different intelligences are encouraged to begin thought. From this new thought schools such as the New York Ross School (SRS) and the Key Learning Community (KLC) became public schools in Indianapolis, owing to their multiplied curriculum of intelligences.

Gardner's intelligence is described as an ability to handle the particular problem content in the world through its completeness phase. But this does not mean that, in every aspect of their lives, persons with such intelligence, such as musical intelligence, can display this ability. Each person has eight kinds of intelligence on a variety of levels. A central component and features of all eight forms of intelligence. The existence of characteristics in an individual determines the degree of intelligence.

In lifereal, the intelligences are present in one or more behaviors and appear together or sequentially. In another specific case, people are accused of being academics, that is to say, people whose intelligence is very high in one form of intelligence, but is very poor in the other.

The principle of multiple intelligentsia has started to be embraced in the field of education because it is meant to better serve all children's intelligences. The MI definition helps educators to see differences and promotes acceptance and service to children. This definition "erases" the idea of intelligent and unintelligent children, as all children are intelligent under this concept. It is just important to redefine the smart term on a new basis. 


\section{Key Points in Multiple Intelligence Theory}

There are numerous items which have to be considered according to the theory of multiple inteligences; (1) everybody has all 8 intelligences; it is just that the profile of every individual can be distinct. Some of them are high in all types of intelligence; some are only high on average and high in two or three different types of intelligence; (2) each intellect can be developed to an acceptable standard of mastery; intelligence can be stimulated, developed to the full by enrichment, encouragement and teaching. In everyday work, knowledge is linked to each other in a variety of ways: the kick of a goal, self-orientation (spatial), protest against the referee (linguistic and interpersonal).

\section{Brief Characteristics of Intelligence}

Howard Gardner points out that each intelligence has characteristics that can be categorized into one particular type of intelligence. When related to the core components are as follows;

\section{Linguistic Intelligence (word smart)}

\section{Definition}

Intelligence of language or intelligence of language. People with this understanding are fantastic at word processing. Any of them are known of (for example: presenters, clergy, storytellers, mc, etc.). Some of them write well (for example: novelists, book writers, etc.). But a few master both of them too.

\section{Characteristic features}

Would read, would like to write (poetry, novels, newspaper books), would like to play scrapy or complete puzzles, would be nice at stories, would like to slip or write words, would rather hear orally (auditory), would love to remember strange words, would like to play with others, would love to talk in words, would like to talk in words, would have lots of vocabulary and would easily find a language.

\section{Development}

In reading books, magazines, and other literature, this intelligence is mainly established. It's nice to get used to something writing (experiences of everyday life, or whatever is gained while reading something, watching a movie, or doing quiet time).

\section{Another supportive intelligence}

It would be better if it is supported by the development of self-smart, smart logic, and people smart. The three intelligences will further enhance your ability to process words, and broaden your horizons.

\section{Suitable work}

$\mathrm{MC}$, presenter, clergyman, trainer, radio announcer, teacher, editor, story teller, public relations, writer, writer, copywriter, comedian.

\section{Spatial Intelligence (picture smart)}

\section{Definition}

Intelligence in space or the intelligence of images. People with this intelligence have a good imagination and are very quick to remember images. This picture is clearly drawn in his mind when he imagines something. Generally, people also have the ability to draw from this intellect. In general, artists are people who are cleverly imaged. In addition to being in your imagination, the benefits of smart owners are in your eyes as well. They generally have alert or watchful eyes for things we can't see.

\section{Characteristic features}

If you have no trouble reading charts, you're interested in pictures than in writing, you are color sensitive, like photography or video, you can picture things viewed at various angles, you like to write while playing puzzles 
on your phone and when you speak to people, you like simplifying something, reads comic books, you like to think (facile to imagine), and you're sensitive to layout (intermediate).

\section{Development}

Only draw more. Draw more. If you read, consider drawing out the important points that you get so you can recall them more quickly. Try adding if you write some notes. Pictures of your notes. Better yet, if you make a drawing diary. Read several books with a range of fascinating views (design books, photography, etc.).

\section{Another supportive intelligence}

Another intellect that is most supportive is smart nature. Nature is typically an unending source of artists' inspiration. Different other intelligences are required in the working environment to help your smart picture. In order to help your smart image, intelligent reasoning is often also required. Smart words are often required by even a graphic designer.

Other suitable jobs

Graphic designers, architects, interior designers, sculptors / sculptors, photographers, cameramen, illustrators, comic artists, painters, product designers, animators, and so on.

\section{Other suitable jobs}

Scientists, science teachers / teachers, accountants, data analysts, programmers, economists, engineers (mechanical, civil, electrical, chemical), researchers, statisticians.

\section{Mathematical intelligence (logic smart)}

\section{Definition}

Math or analytical intelligence. Math. Persons who typically practice this intelligence in research, for example in physics and math. Many that have this intellect are able to think and have good analytical abilities, even though their reasoning is rigid. Logic intelligent people are rational and often try for answers to different questions. But it needs to be monitored because smart people usually want to look for explanations for anything, so it is hard for them to believe in a miraculous Deity. In general, atheists are divided into two classes. The first group consists of people disappointed by God or faith. The second is intelligent logic people, who are searching for explanations and analysis of God.

\section{Characteristic features}

Excellent in maths and physics, likes to ask 'why' about everything, easy to store numbers, likes to examine things, believes everything's caused/motivated, takes an interest in technology and latest discoveries, likes detectives/ mysteries, chronological/organic/secular acts, wonders or arguments (science fiction).

\section{Another supportive intelligence}

People are smart in adding insight and mates, so nerds and weirdos won't be noticed. Smart nature is also important to stimulate the brain to recognize different questions that can enrich your knowledge. Music is clever, since music is said to be able to optimize people's jobs. Able to "rack" minds for those who prefer.

\section{Kinesthetic intelligence (body smart)}

\section{Definition}

Capable of regulating body components' movement, balance, coordination and texture. In general, sports and activities that depend on physicality are really enjoyed by people with a clever body. Clever body people can hardly remain quiet and are very active. Yet body knowledge is not just a matter of physical exercise and endurance. It is also an ability that people with a body understanding have to take on a job and to imitate those behaviours. Have you always been able to see people who want to do something (e.g. machinery, electronics or women's sewing)? They may even be people with an intelligent body.

\section{Characteristic features}


Likes to exercise, likes other people's actions or gestures, loves to dance, likes outdoor activities. It doesn't feel comfortable sitting still for long periods, it likes activities which involves the knowledge of the hands, when thought typically must be moved. Many members move when speaking (for example bungee jumping).

\section{Development}

Exercise to improve kinesthetic intelligence can be carried out. In addition, try to grow this hobby for those who like craftsmanship. They will learn to tinker with machines or computer devices for men. They will make different knuckles and accessories for women in the meantime. You will learn from origami, clay, weaving, folding, and many other skills books.

\section{Another supportive intelligence}

Indirectly, there is no need for any other intelligence. In accordance with the area of work. Smart reasoning is often important to evaluate the skills and limitations of the opponent, for example, as well as to examine the circumstances of the field and the environment. The sportsman will plan the best strategy to improve his chances of success by getting strong analytical qualifications.

Other suitable jobs

Athletes, dancers, craftsmen, magicians, hairdressers, tailors, actors, stuntmen, mechanics, and so on.

\section{Music Intelligence (music smart)}

\section{Definition}

The taste doesn't need to be explained again. For those of you who really like music and have a talent in music, it is certain that you are a person who has musical intelligence.

\section{Characteristic features}

Whistle liking, quickly memorizes the sound of a song you just played, master a certain musical instrument, sensitivity towards fake music, likes to work while singing or humming, a keen interest in understanding the creation of world music, in acquainting with different types of musical rhythms.

\section{Development}

Listen a lot of different types of music. Try to master as many instruments as you can, but one instrument must be mastered to be proficient. Form a band and practice together. Taking classes or finding a teacher will also be better at improving your musical skills. If you have time to spare and you are in a good mood, try creating your own song.

\section{Another supportive intelligence}

No other intelligence is needed immediately. However, you need indirectly clever body, self clever phrase, clever picture and clever nature to create your clever music. Body smart is needed because you have to play a musical instrument using skills and body coordination (except for the vocalist of course). Self intelligent and word intelligent are good for you who like the production of songs. Image intelligent or nature intelligent is nice to grow a right brain since the right brain is often used for playing Music.

\section{Other suitable jobs}

Of course, everything related to music, from being a music player, vocalist, jingle maker, arranger, songwriter, and so on.

\section{Interpersonal Intelligence (people smart)}

\section{Definition}


People with this intelligence have high social abilities. Easy to connect and communicate with other people. In addition, people with this intelligence are able to position themselves and read the situations of those around them. He can quickly adapt to a new environment. Group activities will be preferred.

\section{Characteristic features}

No other intelligence is needed immediately. But you also have to indirectly create your intelligent music with intelligent body, smooth language, smart images and smart nature. Body smart is important because you want to play musical instruments with skills and coordination of body (except for the vocalist of course). Identify yourself cleverly and smart words for those of you who like music. Smart picture or nature smart is ideal for growing the right brain, since the right brain is also used to play music.

\section{Development}

Mix with and research the attributes of as many people as possible. Learn to know what they want and don't like. This will help you develop new people's relationships. Participate in numerous organisations and participate in several life building societies. Extend your horizons, because you have a lot of information to talk and tell when you meet a lot of people.

\section{Another supportive intelligence}

The main thing is word smart. With good word processing, your social skills will be more effective. Other intelligence is also needed, but it depends on the type of job you have.

\section{Other suitable jobs}

Entrepreneurs, public relations, psychologists, counselors, marketing, politicians, trainers, social activists, reporters, sociologists, etc.

\section{Intrapersonal Intelligence (self smart)}

\section{Definition}

An individual who can understand himself is an intelligent person. He knows his life aims, his objectives to be accomplished, his shortcomings and ability. Moreover, people with this intelligence will often look at themselves and benefit from different life events. In fact, this is what everybody should be as intelligent as possible. This intelligence is crucial to take important decisions and resolve the issues that occur in our lives.

\section{Characteristic features}

Living alone can bear with a role even if there are many people who disagree, appear to be ignorant (ignorant), always looks on himself, knows his own strengths, regularly likes to think about his future and his plans of life, is rational, he can gradually face failure and withdraw.

\section{Development}

Quiet time is a very effective way to develop your self smart. Periodically evaluate yourself. Ask yourself, "What is my life goal?", "What do I want to achieve in the near and long term?", "What potential and strengths do I have?" Another way to develop your own smart self is to take time to reflect. Then record the results of your contemplation.

\section{Another supportive intelligence}

Additional intelligences are useful to encourage our smart growth. People of intelligent music, for example, find it easier to ponder with song help. People with an intelligent disposition can do introspection more easily when opened. Those with an intelligent image may use pictures to give the effects of their thoughts easier to remember.

Other suitable jobs

All jobs require self-smart so that we can reach our maximum potential in our work.

\section{Naturalist Intelligence (nature smart)}




\section{Definition}

Simply put, people with an intelligent disposition are people who value the world and nature. He enjoys tourism and outdoor sports of all sorts. Typically a naturally intelligent person who loves raising animals or plant care.

\section{Characteristic features}

Loves touring or hiking (climbing mountains), loves beach and mountain attractions, loves cook, likes photography and video graphing, likes to watch television shows about flora and fauna, quick to remember the spot, likes to camp in the open air, enjoying a holiday in the safari or zoo park.

\section{Development}

You can create your own garden and collect different types of plants for flora enthusiasts. Try keeping those animals for animal lovers. Read several flora and fauna books. Join different societies which often take walks, walks outdoors, etc.

\section{Another supportive intelligence}

Body smart, because you need a strong enough stamina to go up a mountain or camp in the open. In addition, other intelligences do not directly affect a nature smart person.

\section{Other suitable jobs}

Archaeologists, astronomers, botanists, biologists, environmental researchers, florists, landscape architects, sailors, veterinarians, nature photographers and so on.

\section{Learning with the Implementation of Multiple Intelligences}

Basically, everybody has eight possible intelligences, linguistic/linguistic intelligence, logical and mathematical intelligence, visual spatial intelligence, physiological intelligence, interpersonal intelligency, intra-personal intelligency and linguistic intelligence, since everyone has the same brain structure. Therefore, it is important for educators, through the application of several intelligences, to establish learning strategies.

In order to understand a topic and child has a different intelligence and skill. A teacher should not require his students to understand each lesson with a single measure of intelligence with the same understanding because the condition of children in one class is different. An instructor is obligated to accept his life and all his abilities under all forms of student conditions. An educator should consider and value his or her students' abilities and work.4 The principle of multi-intelligence may be best suited to educators' use in helping them understand.

Educators could discuss and describe the activities of a student with multiple intelligences involving: (1) linguistic intelligence (language) discussing and describing alphabetical activity; phonics (sound); pronunciation or speech; reading: writing; hearing; talking and oral information; playing word games; and performing crossworks.

Smart logic, the explanation of events involving numbers and numbers, different patterns, arithmetic, computer; calculation, geometry, statistics; odds, problem solve, logic, strategy games, graphics;, mathematical intelligence

The kinese intellect (smart body), the action and abilities of large and small muscles; physical activity; the creation of a plan or object; demonstration; modelling; dance; sports; physical exercise; the language of your body; the coordination of your eyes;

Music intelligence (smart music), discussing and explaining practices that include vocal and instrumental listening and creating music; reproducing melodies; examining and responding to sound, atmosphere and sound; engaging in rhythmic movements; creating rhythms;

Interpersonal intelligence (intelligent people), debate and explanation of events involving cooperative learning groups (learning together), community ventures, dispute resolution (consciousness), school and student association duties, polite and ethic life, empathy, 
IT (self clever), explaining and describing behaviors including thinking, sentiments, self-analysis, self trust, freedom, self-esteem, management of time, future planning.

Naturalistic intellect, debate and explanation of events concerning the climate and nature, flora and fauna.

Through the cooperation to perfect the strengths and limitations of each understanding, the above eight intelligences can also be related and produce the highest results. A kid has a different intellect. And every boy, of course, has more than one mind. Maximum results will be obtained from this combination.

In developing the idea of multiple intelligences and embracing this theory within the field of education, educators inevitably need to help children grow and build programs that provide a forum for the growth of all kinds of their intelligence to be applied, implemented and evaluated. This role is so important in order to help children solve their challenges and attain life itself, considering the growth and realization of all kinds of intelligence.

The MI definition recognizes and serves the individual differences between learners with a belief that Howard Gardner has stated:

"We are all so different because in essence we have different combinations of intelligences. If we realize this, at least we are more likely to be able to deal with the various problems we face in life in the world correctly."

The MI application in learning would allow educators to be wiser and understand and encourage the assessment of child growth. In order to determine a form of intelligence, many intelligences need to be truthful and equal. Gardner recommends that teachers give students concrete artifacts for all knowledge fields to be manipulated. Using the DMIT (Dermathologist Multiple Intelligence Test), multiple Intelligence by 10 hand fingerprints can be tested even today. Gardner's multiple intelligence can be evaluated using the DMIT (Multiple Intelligence Test). And it is believed that five lobes of the hemisphere have each finger. We will discover a person's innate talent for all ages with the new technology-based aptitude recognition tests. Parents in Multiple Intelligence play the role of parents to handle their own children as home experts. Responsive teachers from their respective parents will easily gain an awareness of child strength and weaknesses. At the beginning of the school year a number of schools follow the official conference program. It is recommended to talk to the parents. Formulas are sent home so parents are aware of what they expect and are able to share information about the strengths, shortcomings, interest, experiences and parenting activities of their children6. Formulae are sent back to parents to learn about the power, limitations, preferences, experiences, and extracurricular activities of their child, and are ready to share them6. Parents are encouraged to talk to each other. Forms are forwarded so that parents know what to expect and are able to share knowledge about the strengths, shortcomings, interests, experiences and extracurricular activities of their children.

\section{Conclusion}

Intelligence is the capacity of an individual to solve the problem including skills, know-how and experience. Intelligence is the capacity of a person to solve the problem by means of information, experience and expertise. Each person has 8 types of intelligence, linguistic, logical-mathematical, visual-spatial, kinesthetic, interpersonal, intra-personal, musical and naturalistic. Every single person actually has eight different forms of intelligence: linguistic, logical-mathematical, visual-space, kinesthetic, interpersonal, intra-personal, musical and naturalistic. However, each individual's mixture and part of intelligence is not the same depending on how all the already existent intelligence is produced. However, each person's mixture and part of the intelligence is not the same depending on how the intelligence already exists evolves. The correct learning methods are used to apply the information available to students and to optimize existing intelligence. The best learning methods are used to incorporate students' intelligence and to optimize established intelligence. If an educator understands and aims to cultivate the innocence that his students have, all the potentials of the protected individual can be properly exploited and not in vain. When an instructor understands and tries to draw on the creativity of his students, all the potentials in the protegé can be adequately exploited and his participation is not in vain. Equipped with a compound theory of intelligence, a professor may learn different methods of learning indirectly. With a principle of compound intelligence, an instructor will learn different learning methods indirectly.

In order to make teachers work as instructors, coaches, trainers, consultants, mentors, engines, generators, assessors to make the most of the students. When each person is born with a spectrum of knowledge, educators are not only supposed to believe that intelligent and successful students are only intelligent academics. And in 
addition to academic abilities, there are different other major potential that students have. The 8 intelligences will interact with one another independently.

\section{References}

Jasmine, Julia. 2007. Profesional's Guide: Teaching With Multiple Intelegence Purwanto:Panduan Praktis Mengajar Berbasis Multiple Intelegences. Bandung: Nuansa.

Gardner, Howard. 1996. Intelegence Multiple Perspectives. USA: Thomson Learning. , Howard. 2003. Multiple Intelegence (kecerdasan Majemuk) Teori dan Praktek. Jakarta: Interaksa

Musfiroh, Tadkiroatun. "Multiple Intelligences dan Implikasinya dalam Pendidikan". Pusdi PAUD. Lemlit UNY, http//multiple-intelegence.com diakses tanggal 15 Oktober 2014

Asrifan, A. (2009). Using songs in teaching English language for the young learners. ParePare: unpublished.

Puasa, K., Asrifan, A., \& Chen, Y. (2017). Classroom Talk in Bilingual Class Interaction. Research in Pedagogy, 7(1), 106121.

Nadirah, N., Tahir, M. H., \& Asrifan, A. (2019). THE ABILITY TO TRANSLATE ENGLISH PHRASES INTO INDONESIAN AND THE DIFFICULTIES FACED BY THE ELEVENTH GRADE STUDENTS OF SMAN 1 PANCARIJANG. JOURNAL OF ADVANCED ENGLISH STUDIES, 2(1), 41-46.

Apdy, A. P. R., \& Asrifan, A. (2019, April). The Chinese mime game in teaching vocabulary on EFL classroom. In PROCEEDINGS OF THE 65th TEFLIN INTERNATIONAL CONFERENCE (Vol. 65, No. 01).

Taslim, T., Asrifan, A., Chen, Y., \& Nurdania, N. R. (2019). CORRELATION BETWEEN STUDENT'S VOCABULARY MASTERY AND SPEAKING SKILL. JOURNAL OF ADVANCED ENGLISH STUDIES, 2(2), 65-76.

Muthmainnah, M., Asrifan, A., Al Yakin, A., \& Sahabuddin, C. (2019, April). The use of dictogloss technique on ELT classroom: An experiment study of students listening comprehension. In PROCEEDINGS OF THE 65th TEFLIN INTERNATIONAL CONFERENCE (Vol. 65, No. 01).

Mutmainnah, M., Azis, S., Maulidya, U., \& Asrifan, A. (2017). Glory Style in Mandar Song Lyrics: A study of Mandar Tribe in South Sulawesi, Indonesia. JOURNAL OF ADVANCES IN LINGUISTICS, 8(1), 1286-1291.

Asrifan, A., Rinantanti, Y., Tang, S., \& Nadirah, N. (2019). THE 3-DIMENSION PICTURES IN INCREASING THE STUDENTS ABILITY AND INTEREST TO WRITE DESCRIPTIVE COMPOSITION. JOURNAL OF ADVANCED ENGLISH STUDIES, 2(1), 19-30.

Asrifan, A., Nadira, N., \& Haedar, H. (2018). IMPROVING STUDENTS'READING COMPREHENSION OF DESCRIPTIVE TEXT THROUGH COLLABORATIVE MURDER. JOURNAL OF ADVANCED ENGLISH STUDIES, 1(2), 21-31.

Asrifan, A. (2015). Analysis of English Students' Learning Style in Bilingual Class. International Journal of Literature and Arts, 3(4), 34 .

Farahdiba, S., \& Asrifan, A. (2016). Speaking Ability and Psychological Barriers of the Second Year Students of Hotel Department of SMKN 1 Sidenreng Kabupaten Sidrap in Speaking English. Asian EFL Journal, (89), 41.

Asrifan, A. (2012). Increasing the Students Ability to Write Descriptive Composition at SMP Negeri 13 Parepare by using the 3-Dimension Pictures.

Tang, S., Asrifan, A., Chen, Y., Haedar, H., \& Agussalim, M. (2019). THE HUMOR STORY IN TEACHING READING COMPREHENSION. JOURNAL OF ADVANCED ENGLISH STUDIES, 2(2), 77-87.

Nurwanti, N., Asrifan, A., \& Haedar, H. (2019). THE APPLICATION OF COOPERATIVE LEARNING: JIGSAW II TECHNIQUE IN IMPROVING STUDENTS'READING COMPREHENSION OF EXPOSITORY TEXT. JOURNAL OF ADVANCED ENGLISH STUDIES, 2(1), 31-40.

Asrifan, A. (2016). The Effectiveness of Think-Pair-Share Technique in Improving Studentsâ€TM Speaking Ability and Interest. English Literature and Language Review, 2(3), 24-35. 
Asrifan, A., Muthmainnah, M., Al-Yakin, A., Sahabuddin, C., \& Haedar, H. (2018). THE CAUSE-EFFECT TECHNIQUE IN TEACHING RECOUNT WRITING. JOURNAL OF ADVANCED ENGLISH STUDIES, 1(2), 63-72.

Asrifan, A., Vargheese, K. J., Syamsu, T., \& Amir, M. (2020). ESP COURSE DESIGN: THE NEED ANALYSIS ON TOURISM DEPARTMENT IN INDONESIA VOCATIONAL HIGH SCHOOLS. JOURNAL OF ADVANCED ENGLISH STUDIES, 3(2), 69-77.

Asrifan, A., Ghofur, A., \& Azizah, N. (2020). Cheating Behavior in EFL Classroom (A Case Study at Elementary School in Sidenreng Rappang Regency). OKARA: Jurnal Bahasa dan Sastra, 14(2), 279-297.

Nadirah, N., Asrifan, A., Vargheese, K. J., \& Haedar, H. (2020). INTERACTIVE MULTIMEDIA IN EFL CLASSROOM: A STUDY OF TEACHING READING COMPREHENSION AT JUNIOR HIGH SCHOOL IN INDONESIA. JOURNAL OF ADVANCED ENGLISH STUDIES, 3(2), 131-145.

Muthmainnah, A. R., Atmowardoyo, H., Salija, K., \& Asrifan, A. (2020). Literary Work as Teaching Materials: A Study of Students and Lecturers Needs Analysis. Solid State Technology, 63(5), 394-407.

Tilome, A. A., Agustang, A., Jasruddin, M. S., \& Asrifan, A. (2020). Social Exchange of Political Elites in the Regional Leader Election of Gorontalo Province, Indonesia. Solid State Technology, 63(5), 521-531.

Pacinongi, A., \& Asrifan, A. (2020). Bimbingan Pengawas Berkelanjutan dalam Mewujudkan Pendidikan Karakter Bangsa dalam Kegiatan Belajar Mengajar Penjaskes. Celebes Education Review, 2(1), 1-7.

Gunawan, G., \& Asrifan, A. (2020). Penerapan Kerja Kelompok Kegiatan MGMP Guru Ekonomi dalam Menyusun RPP untuk Meningkatkan Kompetensi Pedagogik. Celebes Education Review, 2(1), 31-36.

Yusuf, I., \& Asrifan, A. PENINGKATAN AKTIVITAS KOLABORASI PEMBELAJARAN FISIKA MELALUI PENDEKATAN STEM DENGAN PURWARUPA PADA $\quad$ SISWA $\quad$ KELAS XI IPA SMAN 5 YOGYAKARTA. Editorial Team, 32.

Al Yakin, A., Sahabuddin, C., Rahayu, A., Fitrah, N., \& Arifin, M. (2020). Political Celebrification and Electability: A Study of Political Phenomena Imaging in Election Polewali Mandar District, West Sulawesi, Indonesia. Solid State Technology, 63(5), 632-646.

Junaedah, S. B. T., \& Ahmad, M. A. (2020). The Outdoor Learning Modules Based on Traditional Games in Improving Prosocial Behaviour of Early Childhood. International Education Studies, 13(10).

Octaberlina, L. R., \& Muslimin, A. I. (2020). Efl students perspective towards online learning barriers and alternatives using moodle/google classroom during covid-19 pandemic. International Journal of Higher Education, 9(6), 1-9.

Octaberlina, L. R., \& Anggarini, I. F. (2020). Teaching vocabulary through picture cards in Islamic Elementary School: a case study in Nida Suksa School, Thailand. Jurnal Madrasah, 13(1), 26-38.

Octaberlina, L. R. (2016). Plagiarism in English language theses in Indonesia. Jurnal Ilmu Pendidikan, 14(3).

Octaberlina, L. R., \& Anggarini, I. F. (2020). Teaching vocabulary through picture cards in Islamic Elementary School: a case study in Nida Suksa School, Thailand. Jurnal Madrasah, 13(1), 26-38.

Asrifan, A., Zita, C. T., Vargheese, K. J., Syamsu, T., \& Amir, M. (2020). THE EFFECTS OF CALL (COMPUTER ASSISTED LANGUAGE LEARNING) TOWARD THE STUDENTS'ENGLISH ACHIEVEMENT AND ATTITUDE. JOURNAL OF ADVANCED ENGLISH STUDIES, 3(2), 94-106.

Asrifan, A. (2021). ACADEMIC WRITING. LawArXiv. January, 2. https://doi.org/10.31228/osf.io/x2s7e

Asrifan, A. (2020). TUTORIAL PENGGUNAAN QUIZIZZ (www. quizizz. com) PADA PEMBELAJARAN. https://doi.org/10.31219/osf.io/kqnza

Asrifan, A. (2021). Abd Ghofur.“. THE USE OF READING CIRCLES IN INCREASING STUDENTS SPEAKING ABILITY AT THE ELEVENTH GRADE SMK NEGERI, 1. https://doi.org/10.31219/osf.io/8vjxy

Asrifan, A. (2020). Pandemic, Humanity and Education. https://doi.org/10.31219/osf.io/q2gpk

Asrifan, A. (2021). USING CAT AND MOUSE GAME TO IMPROVE STUDENT'S SPEAKING ABILITY AT THE ELEVENTH GRADE OF MA YMPI RAPPANG. https://doi.org/10.31219/osf.io/phtvn

Asrifan, A., \& Ghofur, A. (2021). THE USE OF READING CIRCLES IN INCREASING STUDENTS SPEAKING ABILITY AT THE ELEVENTH GRADE SMK NEGERI 1 PANCARIJANG. https://doi.org/10.31219/osf.io/8vjxy 
Asrifan, A. (2021). Book Review: Halliday. 1989. Spoken and Written Language. Oxford University Press. https://doi.org/10.31219/osf.io/ej8tb

Asrifan, A., \& Ghofur, A. (2021). TALK, ACTION, SILENCE, INTERRUPTION AND THEIR IMPLICATIONS IN BUGINESE SOCIETY (SOPPENG REGENCY). https://doi.org/10.31219/osf.io/pv3ku

Asrifan, A. (2020). PENILAIAN BERBASIS ANDROID MENGGUNAKAN APLIKASI PLICKERS https://doi.org/10.31219/osf.io/htreq

Haulussy, R. H., Najamuddin, I. R., \& Agustang, A. D. M. P. (2020). The sustainability of the Sasi Lola tradition and customary law (Case study in Masawoy Maluku, Indonesia). Intl J Sci Technol Res, 9(2), 5193-5195.

Arwan, A., Agustang, A., Arlin, A., Yani, A., \& PUTRA, D. M. (2019). Contestation of Elite Discourse in Treatment of HIV and AIDS. Iranian Journal of Public Health, 48(12), 2205.

Mutiara, I. A., Agustang, A., Adam, A., Upe, A., \& Equatora, M. A. (2020). The dynamics of prostitutes lives in metropolitan cities. Journal of Critical Reviews. https://doi. org/10.31838/jcr, 7, 165.

Usman, A., Agustang, A., Djalal, D., \& Annas, S. (2018, October). The Contribution Of Supporter Community In Maximizing Their Role For The Advancement Of Makassar Football Club (PSM). In 1st International Conference on Social Sciences (ICSS 2018). Atlantis Press.

Ma'na, P., Agustang, A., Salusu, J., Ikhsan, A., \& Dirawan, G. D. (2015). Decision making strategic value based local wisdom Tongkonan North Toraja. Man India, 95(3), 633-639.

Dirawan, G. D. FOSTERING COLLABORATION STREET CHILDREN IN MAKASSAR. Man In India, 95(3), 569-576.

Abdurachman, A. D. M. P. A., \& Agustang, A. Culture Of Shame-Heart And Social Solidarity Of Kaitetu People Central Maluku District, Indonesia.

Aida, K. N., Agustang, A., Arlin, A., \& Agustang, A. D. M. The Patron-Client Relationship Patterns In Siwa Lima Fishermen Community, Aru Islands District Maluku, Indonesia.

Pannyiwi, R., Agustang, A., Kasnawi, T., Pada, A. T., Yani, A., \& Syam, S. (2020). Social Network for Drug Circulation in Sidenreng Rappang Regency, Indonesia. Systematic Reviews in Pharmacy, 11(9), 575-577.

Upe, A., Salman, D., \& Agustang, A. (2019). The effects of the exploitation of natural resources towards risk society construction in Southeast Sulawesi Province, Indonesia. Journal of Degraded and Mining Lands Management, 6(2), 1587.

Matakena, F., Watloly, A., Agustang, A., Adam, A., \& Alim, A. (2020). The Self-Concept of Ale Rasa Beta Rasa in the Orang Basudara Community in Ambon (Studies on the Community of Passo and Batumerah Country). International Journal, 9, 1307 .

Asmi, A. S., Kasnawi, M. T., Agustang, A., \& Yani, A. (2020). Sociocultural Transformation in Efforts to Reduce Mortality of Infants in Bone Regency, Indonesia. Systematic Reviews in Pharmacy, 11(10), 762-765.

Usmana, A., \& Agustangb, A. The Implementation of “Arif” Social Behaviour within Perssin Supporters in Sinjai District.

Hasan, I. R., Agustang, A., Kahar, F., \& Tahir, H. (2019). Super Service Delivery": an advanced conceptual model of onestop service for wide administrative region. Problems and perspectives in management, (17, Iss. 1), 189-201.

Asrifan, A. (2021). ISSUES IN TEFL “International Article Summary \& Presentation": Students' Reactions to School Based Oral Assessment: Bridging the Gap in Malaysia. https://doi.org/10.31228/osf.io/te3m5

Asrifan, A., Al Yakin, A., \& Sahabuddin, C. The Use of Dictogloss Technique on ELT Classroom: An Experiment Study of Students Listening Comprehension.

Octaberlina, L. R., \& Asrifan, A. (2021). THE USE OF HUMOR STORY IN IMPROVING THE STUDENTS'READING COMPREHENSION. https://doi.org/10.31219/osf.io/kvsbe

Octaberlina, L. R., \& Asrifan, A. (2021). THE TEXT-BASED CHARACTER IN TEACHING READING COMPREHENSION AT THE TENTH GRADE STUDENTS. https://doi.org/10.31219/osf.io/p53sn

Asrifan, A. (2021). CODE MIXING AND CODE SWITCHING IN THE EFL CLASSROOM INTERACTION. https://doi.org/10.31228/osf.io/xd45c 
Asrifan, A. (2021). Book Review: Halliday. 1989. Spoken and Written Language. Oxford University Press. https://doi.org/10.31219/osf.io/ej8tb

Asrifan, A. (2021). ADVANCED GRAMMAR “Adverbs and Adverb Clauses”. https://doi.org/10.31228/osf.io/cuh83

Asrifan, A. (2020). TUTORIAL PENGGUNAAN QUIZIZZ (www. quizizz. com) PADA PEMBELAJARAN. https://doi.org/10.31219/osf.io/kqnza

Asrifan, A., \& Aeni, N. Book Review: I SPEAK FIVE LANGUAGES: FOSTERING PLURILINGUAL COMPETENCE THROUGH LANGUAGE AWARENESS By: Oliveira and Helena, Maria. https://doi.org/10.31228/osf.io/tjnq9

Asrifan, A. (2021). Modul Perkuliahan RESEARCH ON ENGLISH LANGUAGE TEACHING. https://doi.org/10.31219/osf.io/5rgvc

Asrifan, A. (2021). IMPROVING STUDENTS'SPEAKING ABILITY BY USING HAND DOLLS OF THE ELEVENTH GRADE STUDENTS OF MA YMPI RAPPANG. https://doi.org/10.31219/osf.io/zfhqu

Asrifan, A., Octaberlina, L. R., \& Handayani, R. (2021). SEMANTIC ANALYSIS ON THE USE OF ENGLISH LANGUAGE SLOGAN. https://doi.org/10.35542/osf.io/vtx5y

Asrifan, A. (2021). Book Review KONSTRUKSI GROUNDED TEORI Petunjuk Praktis Dalam Analisa Kualitatif Written By: Kathy Charmez. https://doi.org/10.31228/osf.io/nt8yk

Qisti, N., Nurwidah, A., Muslimin, I., \& Asrifan, A. (2020). THE EFFECT OF TEMPERATURE AND TIME DRYING TOWARD ORGANOLEPTIC QUALITY OF THE DUCKS BONE MEAL. Solid State Technology, 63(6), 1965219659.

Asrifan, A., \& Ghofur, A. Book Review: Writing for Academic Journals Second Edition https://doi.org/10.31219/osf.io/su3ya 